\title{
PD-1/PD-L1 immune checkpoint inhibitors in advanced cervical cancer
}

\author{
Ozlen Saglam ${ }^{1 *}$ and Jose Conejo-Garcia ${ }^{2}$ \\ ${ }^{1}$ Department of Anatomic Pathology, Moffitt Cancer Center, USA \\ ${ }^{2}$ Department of Immunology, Moffitt Cancer Center, USA
}

\begin{abstract}
Programmed cell death-1 and programmed cell death ligand-1 (PD-1/PD-L1) blockage has become an important treatment modality after approval of pembrolizumab and nivolumab by Food and Drug Administration in advanced cancers. Patients with metastatic and recurrent cervical cancer have limited treatment options and usually receive palliative platinum-based chemotherapy without significant survival benefit. Recent studies provided support for usage of immune checkpoint inhibitors in advanced cervical cancer. Around 35\% of cervical squamous cell carcinoma (C-SCC) and 17\% of adenocarcinomas expressed PD-L1. Human Papilloma Virus status was also correlated with PD-L1 expression. PD-1/PD-L1 expression in tumor infiltrating inflammatory cells was higher in cervical cancer in comparison to endometrial and ovarian adenocarcinomas. In C-SCC diffuse PD-L1 expression as compared to marginal PD-L1 expression on the interface between tumor and stroma was a risk factor for poor disease-free and disease-specific survival rates. Higher numbers of infiltrating regulatory $\mathrm{T}$ cells in PD-L1 positive tumors was associated with better prognosis. The studies performed on other cancer types revealed PD-L1 tumor heterogeneity and transient marker expression. Drug-resistance to immune checkpoint inhibitors is also a potential problem. Currently Phase I/II clinical trials evaluating effects of PD-1 therapy are in progress for cervical carcinoma. Additional studies are required to develop novel biomarkers and for standard evaluation of PD-L1 testing in order to predict response to immune checkpoint inhibitors in all cancer types including cervical carcinoma.
\end{abstract}

\section{Introduction}

Cervical cancer is the third common gynecologic cancer and will affect 13,240 women in the United Stated with an estimated 4,170 deaths in 2018 [1]. Human Papilloma Virus (HPV) infection is an etiologic agent of precursor lesions, Cervical Intraepithelial Neoplasia (CIN), and invasive cervical carcinoma [2]. High-risk HPV subtypes, HPV 16 and 18 are the most carcinogenic types in progression of the disease [3]. In the last few decades, effective screening and preventive vaccines facilitated early detection of precursor lesions and improved survival outcomes [4]. For early staged cancer surgical removal through radical hysterectomy is the treatment of choice and concurrent chemoradiation (CCRT) is the standard treatment modality for locally advanced disease defined as stages IB2-IVA by International Federation of Gynecology and Obstetrics [5]. Recurrent and metastatic diseases develop in 15-61\% of the women within the first two years after completion of primary treatment [6]. The management of recurrent cervical cancer depends on previous therapeutic modalities. In the presence of prior pelvic irradiation the prognosis is usually dismal and only curative therapy is pelvic exenteration procedure with high morbidity and mortality rates $[7,8]$.

Majority of patients with recurrent and metastatic cervical carcinoma are treated with palliative chemotherapy [9]. Platinum-based combination therapies are the treatment of choice [10]. The addition of vascular endothelial growth factor inhibitors reduced hazard of disease progression and prolonged overall survival [11]. Epithelial growth factor inhibitors, targeting of PI3K/AKT/mTOR pathway and therapeutic vaccines are other new treatment modalities included in clinical trials of recurrent and metastatic diseases [12-14]. Currently immunotherapy was emphasized as maintenance therapy for highrisk patients with multiple positive pelvic lymph nodes, uterine corpus extension, and positive aortic nodes in patients treated with CCRT [15]. We will discuss below Programmed cell death-1 and programmed cell death ligand-1 (PD-1/PD-L1) immune checkpoint pathway and the potential role of PD-1/PD-L1 blockers in the treatment of cervical carcinoma.

\section{PD-1/PD-L1 Immune checkpoint inhibitors}

The immune checkpoints are critical to maintain tolerance against autoimmunity in physiologic conditions. PD-1 is a transmembrane protein and expressed in $\mathrm{B}$ and $\mathrm{T}$ immune cells. Its receptor $\mathrm{PD}-\mathrm{L} 1$ is a member of B7 family and associated with antigen presenting cells such as dendritic and cancer cells [16]. PD-1 is expressed on memory cells in the peripheral blood of healthy individuals [17]. The PD-1/PD-L1 interactions leads to blockage of $\mathrm{T}$ cell activation by inhibiting TCR signal transduction and CD28-CD80 co-stimulation [18]. Several cancer types overexpress PD-L1, which serves as an immune resistance mechanism by inactivating $\mathrm{T}$ cells within tumor microenvironment $[19,20]$. Food and Drug Administration (FDA) recently approved $\mathrm{PD}-1 / \mathrm{PD}-\mathrm{L} 1$ antibody-mediated blockage for metastatic melanoma, Non-small cell lung cancer (NSCLC), head and neck, kidney and urothelial carcinomas, Hodgkin lymphoma and microsatellite instability/mismatch repair (MMR) deficient cancers [21]. However, PD-1 signaling and the mechanism of action of PD-1/ PD-L1 monoclonal antibodies are not completely understood.

${ }^{\star}$ Correspondence to: Ozlen Saglam, Department of Anatomic Pathology, Moffitt Cancer Center, 12902 USF, Magnolia Dr., Tampa, FL 33612, USA, Tel: 8137451014, E-mail: ozlen.saglam@moffitt.org

Received: March 20, 2018; Accepted: April 10, 2018; Published: April 14, 2018 
At the transcription level INF- $Y$ is the major inducer of PD-L1 expression [22]. PD-L1 expression is also induced on activated immune cells including dendritic cells, macrophages, B cells, T cells and natural killer cells. The latter is mediated through cytokine/chemokine and STAT3 pathways [23]. The expression levels of PD-L1 on tumor cells did not always correlate with response to therapy in the literature [17]. The inconsistency is partly related to non-standard reading and different cutoff levels of PD-L1 antibody positivity. Based on clinical trials and response rates to therapy the predictive $50 \%$ cutoff of PD-L1 expression was included in the FDA indications of pembrolizumab in metastatic NSCLC (24). Another predictor of treatment response is high mutational load of tumors resulting in multiple neoantigens generated from an increased burden of nonsynonymous mutations [25]. The relation between PD-L1 expression levels and overall disease prognosis is also controversial. It has been associated with worse survival in some tumors such as esophageal, gastric, colorectal and pulmonary cancers $[26,27]$. PD-L1 expression on immune cells was a favorable prognostic factor in vulvar Squamous Cell Carcinoma (SCC) [28] and did not have any affect in prognosis in laryngeal and pharyngeal SCC [29].

\section{PD-1/PD-L1 and cervical cancer}

Persistent HPV infection is involved in the pathogenesis of both cervical squamous and adenocarcinomas. The expression levels of PD-1/PD-L1 were studied in relation to HPV status in cervical lesions. In one study there was no difference in mRNA expression of PD-L1 by qRT-PCR when comparing HPV DNA-positive and -negative women [30]. However PD-L1 expression was correlated with HPV-positivity and increased with CIN grade, and tumor metastasis in cervical cancer in a later study [31]. PD-L1 expression was reported in higher rates in squamous type (34\%) compared to adenocarcinoma (17\%) and adenosquamous carcinoma had a positive rate of $29 \%$ [32]. The difficulty in evaluating PD-L1 expression is partly due to heterogeneous nature of tumors. The expression of PD-L1 is not uniform and can be transient, thus PD-L1 immunohistochemistry staining varies with tumor locations $[33,34]$. These results may explain conflicting response rates to $\mathrm{PD}-\mathrm{L} 1$ blockers with low $\mathrm{PD}-\mathrm{L} 1$ expression levels. The genetic basis of increased PD-1/PD-L1 expression was explored in cervical and vulvar SCC samples. The genes encoding PD-L1 and PD-L2, CD274 and PDCD1LG2, were co-amplified or gained extra chromosomes in $67 \%$ of cervical and $43 \%$ of vulvar SCC cases by Florescence in situ hybridization [35].

PD-1/PD-L1 expression levels were also studied in Tumor Infiltrating Inflammatory cells (TIL) in cervical carcinoma. PD-L1 positivity in TIL component of cervical squamous cell cancers was higher in comparison to endometrial and ovarian adenocarcinomas [36]. TIL can also play a role in predicting response to anti-PD-L1 therapies [37] and therefore evaluating amount of TIL and their functional status can be complimentary to PD-L1 expression levels in tumors. Karim et al showed more than half of TIL expressed PD-1 and only $19 \%$ of tumor cells had positivity with PD-L1 in cervical cancers. In addition the expression of PD-L1 did not show a direct impact on patient survival but patients with a relative excess of infiltrating regulatory $\mathrm{T}$ cells displayed a better survival when the tumor was PDL1 positive [38]. The expression levels and pattern were also correlated with survival outcomes in other studies. In SCC of cervix, disease-free and disease-specific survival rates were significantly poorer in patients with diffuse $\mathrm{PD}-\mathrm{L} 1$ expression as compared with patients with marginal PD-L1 expression on the interface between tumor and stroma [39]. The same study showed disease-specific survival was worse in cervical adenocarcinoma patients with PD-L1-positive tumor-associated macrophages compared with adenocarcinoma patients without PDL1-positive tumor-associated macrophages. Contrary to these reports, neither expression of PD-L1 nor density of $\mathrm{CD}^{+} \mathrm{T}$ cells in pretreatment specimen was associated with progression-free or overall survival in patients with advanced cervical cancer in a later study [40].

\section{Immune checkpoint inhibitors and drug resistance}

Another potential problem in immune checkpoint inhibitor treatment is primary and acquired drug resistance [41]. In cervical cancer there is not much data related to duration and mechanisms of drug resistance. A recent clinical trial showed $17 \%$ response rate to anti-PD-L1 treatment in 24 patients with PD-L1 positive tumors [42]. The presence of inactivating mutations in JAK1, JAK2 and beta2microglobin genes in cancer cells correlated with lack of primary response in melanoma and colon cancer [43]. It has also been shown that tumors acquire resistance through PD-L1 up-regulation [44] and can escape immune surveillance by decreased expression of MHC, increased PD-L2 expression on PD-L1 negative tumor cells, stromal remodeling, epithelial mesenchymal transition and compensatory PD-L1 expression on host cells including T cells $[45,46]$. The tumor cells can activate PD-L1 expression independently of inflammatory signals via multiple oncogenic signaling pathways including PI3K/ AKT, ALK/STAT3 and MEK/ERK/STAT1 [47-49]. On the other hand, Transforming Growth Factor-beta (TGF- $\beta$ ) signaling pathway suppresses Th1 and cytotoxic T-cells while promoting the generation and activity of Treg cells [50]. TGF- $\beta$ impairs the adaptive anti-tumor immunity by directly inhibiting clonal expansion and cytotoxicity of $\mathrm{CD}^{+}$cytotoxic $\mathrm{T}$ cells and inducing expression of Foxp3 to suppress $\mathrm{CD}^{+} \mathrm{T}$ cells [51-53]. TGF- $\beta 1$ enhances PD-1 expression through SMAD3 dependent way on antigen-specific $\mathrm{T}$ cells in cancer [54]. In support of latter findings tumor-derived TGF- $\beta$ decreases Special AT-rich sequence protein (Satb1) expression through binding SMAD proteins to its promotor. Satb1 regulates epigenetic regression of PD-1 on activated T cells [55]. Finally lack of response to PD-L1 therapy in metastatic urothelial carcinoma was associated with a signature TGF- $\beta$ signaling in fibroblasts [56].

\section{Conclusion}

Clinical use of immune checkpoint inhibitors is new and promising treatment modality in advanced and recurrent cancers. Currently there are multiple phase I/II clinical trials evaluating effect of anti-PD-1/PDL1 therapy in cervical cancer [57]. Some of these include anti-cytotoxic T-lymphocyte associated antigen (CTLA4) as a combination therapy. Ipilimumab, an anti-CTLA4 antibody, was tolerable in patients with advanced cervical cancer but it did not show significant single-agent activity [58]. Targeting multiple immunologic pathways especially potential antagonists of $\mathrm{PD}-1 / \mathrm{PD}-\mathrm{L} 1$ pathway may overcome innate and acquired resistance to anti-PD-L1 therapy.

\section{Acknowledgement}

Effort for this study was partially supported by R01CA157664, R01CA124515, R01CA178687, and Cancer Center Support Grant (CCSG) CA010815 to H. Lee Moffitt Cancer Center \& Research Institute.

\section{References}

1. Siegel RL, Miller KD, Jemal A (2018) Cancer statistics, 2018. CA: a cancer journal for clinician 68: 7-30.

2. zur Hausen H (2002) Papillomaviruses and cancer: from basic studies to clinical application. Nat Rev Cancer 2: 342-350. [Crossref] 
3. Walboomers JM, Jacobs MV, Manos MM, Bosch FX, Kummer JA, et al. (1999) Human papillomavirus is a necessary cause of invasive cervical cancer worldwide. $J$ Pathol 189: 12-19. [Crossref]

4. Lee SJ, Yang A, Wu TC, Hung CF (2016) Immunotherapy for human papillomavirusassociated disease and cervical cancer: review of clinical and translational research. $J$ Gynecol Oncol 27: e51. [Crossref]

5. Verma J, Monk BJ, Wolfson AH (2016) New Strategies for Multimodality Therapy in Treating Locally Advanced Cervix Cancer. Semin Radiat Oncol 26: 344-348. [Crossref]

6. Pfaendler KS, Tewari KS (2016) Changing paradigms in the systemic treatment of advanced cervical cancer. Am J Obstet Gynecol 214: 22-30. [Crossref]

7. Marnitz S, Köhler C, Müller M, Behrens K, Hasenbein K, et al. (2006) Indications for primary and secondary exenterations in patients with cervical cancer. Gynecol Oncol 103: 1023-1030. [Crossref]

8. Goldberg GL, Sukumvanich P, Einstein MH, Smith HO, Anderson PS, et al. (2006) Total pelvic exenteration: the Albert Einstein College of Medicine/Montefiore Medical Center Experience (1987 to 2003). Gynecol Oncol 101: 261-268. [Crossref]

9. Boussios S, Seraj E, Zarkavelis G, Petrakis D, Kollas A, et al. (2016) Management of patients with recurrent/advanced cervical cancer beyond first line platinum regimens: Where do we stand? A literature review. Crit Rev Oncol Hematol 108: 164-174. [Crossref]

10. Monk BJ, Sill MW, McMeekin DS, Cohn DE, Ramondetta LM, et al. (2009) Phase III trial of four cisplatin-containing doublet combinations in stage IVB, recurrent, or persistent cervical carcinoma: a Gynecologic Oncology Group study. J Clin Oncol 27: 4649-4655. [Crossref]

11. Tewari KS, Sill MW, Long HJ 3rd, Penson RT, Huang H, et al. (2014) Improved survival with bevacizumab in advanced cervical cancer. $N$ Engl J Med 370: 734-743. [Crossref]

12. Monk BJ, Mas Lopez L, Zarba JJ, Oaknin A, Tarpin C, et al. (2010) Phase II, openlabel study of pazopanib or lapatinib monotherapy compared with pazopanib plus lapatinib combination therapy in patients with advanced and recurrent cervical cancer. J Clin Oncol 28: 3562-3569. [Crossref]

13. Tinker AV, Ellard S, Welch S, Moens F, Allo G, et al. (2013) Phase II study of temsirolimus (CCI-779) in women with recurrent, unresectable, locally advanced or metastatic carcinoma of the cervix. A trial of the NCIC Clinical Trials Group (NCIC CTG IND 199). Gynecol Oncol 130: 269-274. [Crossref]

14. Yang A, Farmer E, Lin J, Wu TC, Hung CF (2017) The current state of therapeutic and $\mathrm{T}$ cell-based vaccines against human papillomaviruses. Virus Res 231: 148-165. [Crossref]

15. Sagae S, Monk BJ, Pujade-Lauraine E, Gaffney DK, Narayan K, et al. (2016) Advances and Concepts in Cervical Cancer Trials: A Road Map for the Future. Int J Gynecol Cancer 26: 199-207. [Crossref]

16. Sharpe AH, Wherry EJ, Ahmed R, Freeman GJ (2007) The function of programmed cell death 1 and its ligands in regulating autoimmunity and infection. Nat Immunol 8 239-245. [Crossref]

17. Xu-Monette ZY, Zhang M, Li J, Young KH (2017) PD-1/PD-L1 Blockade: Have We Found the Key to Unleash the Antitumor Immune Response? Front Immunol 8: 1597. [Crossref]

18. Riley JL (2009) PD-1 signaling in primary T cells. Immunol Rev 229: 114-125. [Crossref]

19. Konishi J, Yamazaki K, Azuma M, Kinoshita I, Dosaka-Akita H, et al. (2004) B7-H1 expression on non-small cell lung cancer cells and its relationship with tumor-infiltrating lymphocytes and their PD-1 expression. Clin Cancer Res 10: 5094-5100. [Crossref]

20. Dong H1, Strome SE, Salomao DR, Tamura H, Hirano F, et al. (2002) Tumor-associated B7-H1 promotes T-cell apoptosis: a potential mechanism of immune evasion. Nat Med 8: 793-800. [Crossref]

21. Gong J, Chehrazi-Raffle A, Reddi S, Salgia R (2018) Development of PD-1 and PD-L1 inhibitors as a form of cancer immunotherapy: a comprehensive review of registration trials and future considerations. J Immunother Cancer 6: 8. [Crossref]

22. Brown JA, Dorfman DM, Ma FR, Sullivan EL, Munoz O, et al. (2003) Blockade of programmed death-1 ligands on dendritic cells enhances $\mathrm{T}$ cell activation and cytokine production. J Immunol 170: 1257-1266. [Crossref]

23. Matta BM, Raimondi G, Rosborough BR, Sumpter TL, Thomson AW (2012) IL-27 production and STAT3-dependent upregulation of B7-H1 mediate immune regulatory functions of liver plasmacytoid dendritic cells. J Immunol 188: 5227-5237. [Crossref]
24. Reck M, Rodriguez-Abreu D, Robinson AG, Hui R, Csoszi T, et al. (2016) Pembrolizumab versus Chemotherapy for PD-L1-Positive Non-Small-Cell Lung Cancer. N Eng J Med 375: 1823-1833. [Crossref]

25. Dijkstra KK, Voabil P, Schumacher TN, Voest EE (2016) Genomics- and Transcriptomics-Based Patient Selection for Cancer Treatment With Immune Checkpoint Inhibitors: A Review. JAMA Oncol 2: 1490-1495. [Crossref]

26. Wu P, Wu D, Li L, Chai Y, Huang J (2015) PD-L1 and Survival in Solid Tumors: A Meta-Analysis. PLoS One 10: e131403. [Crossref]

27. Koh J, Go H, Keam B, Kim MY, Nam SJ, et al. (2015) Clinicopathologic analysis of programmed cell death-1 and programmed cell death-ligand 1 and 2 expression in pulmonary adenocarcinoma: comparison with histology and driver oncogenic alteration status. Mod Pathol 28: 1154-11566. [Crossref]

28. Sznurkowski JJ, Zawrocki A, Sznurkowska K, Peksa R, Biernat W (2017) PD-L expression on immune cells is a favorable prognostic factor for vulvar squamous cell carcinoma patients. Oncotarget 8: 89903-89912. [Crossref]

29. Karpathiou G, Casteillo F, Giroult JB, Forest F, Fournel P, et al. (2017) Prognostic impact of immune microenvironment in laryngeal and pharyngeal squamous cell carcinoma: Immune cell subtypes, immuno-suppressive pathways and clinicopathologic characteristics. Oncotarget 8: 19310-19322. [Crossref]

30. Brismar Wendel S, Kaldensjo T, Peterson P, Andersson S, Broliden K, et al. (2010) Slumbering mucosal immune response in the cervix of human papillomavirus DNApositive and -negative women. Int J Oncol 37: 1565-1573. [Crossref]

31. Yang W, Lu YP, Yang YZ, Kang JR, Jin YD, et al. (2017) Expressions of programmed death (PD)-1 and PD-1 ligand (PD-L1) in cervical intraepithelial neoplasia and cervical squamous cell carcinomas are of prognostic value and associated with human papillomavirus status. J Obstet Gynaecol Res 43: 1602-1612. [Crossref]

32. Reddy OL, Shintaku PI, Moatamed NA (2017) Programmed death-ligand 1 (PD-L1) is expressed in a significant number of the uterine cervical carcinomas. Diagn Pathol 12: 45. [Crossref]

33. Noguchi T, Ward JP, Gubin MM, Arthur CD, Lee SH, et al. (2017) Temporally Distinct PD-L1 Expression by Tumor and Host Cells Contributes to Immune Escape. Cancer Immunol Res 5: 106-117. [Crossref]

34. Kleinovink JW, Marijt KA, Schoonderwoerd MJA, van Hall T, Ossendorp F, et al (2017) PD-L1 expression on malignant cells is no prerequisite for checkpoint therapy. Oncoimmunology 6: e1294299. [Crossref]

35. Howitt BE, Sun HH, Roemer MG, Kelley A, Chapuy B, et al. (2016) Genetic Basis for PD-L1 Expression in Squamous Cell Carcinomas of the Cervix and Vulva. JAMA Oncol 2: 518-522. [Crossref]

36. Mezache L, Paniccia B, Nyinawabera A, Nuovo GJ (2015) Enhanced expression of PD L1 in cervical intraepithelial neoplasia and cervical cancers. Mod Pathol 28: 15941602. [Crossref]

37. Festino L, Botti G, Lorigan P, Masucci GV, Hipp JD, et al. (2016) Cancer Treatment with Anti-PD-1/PD-L1 Agents: Is PD-L1 Expression a Biomarker for Patient Selection? Drugs 76: 925-945. [Crossref]

38. Karim R, Jordanova ES, Piersma SJ, Kenter GG, Chen L, et al. (2009) Tumor-expressed B7-H1 and B7-DC in relation to PD-1+ T-cell infiltration and survival of patients with cervical carcinoma. Clin Cancer Res 15: 6341-6347. [Crossref]

39. Heeren AM, Punt S, Bleeker MC, Gaarenstroom KN, van der Velden J, et al. (2016) Prognostic effect of different PD-L1 expression patterns in squamous cell carcinoma and adenocarcinoma of the cervix. Mod Pathol 29: 753-763. [Crossref]

40. Enwere EK, Kornaga EN, Dean M, Koulis TA, Phan T, et al. (2017) Expression of PD-L1 and presence of CD8-positive T cells in pre-treatment specimens of locally advanced cervical cancer. Mod Pathol 30: 577-586. [Crossref]

41. Jenkins RW, Barbie DA, Flaherty KT (2018) Mechanisms of resistance to immune checkpoint inhibitors. Br J Cancer 118: 9-16. [Crossref]

42. Frenel JS, Le Tourneau C, O’Neil B, Ott PA, Piha-Paul SA, et al. (2017) Safety and Efficacy of Pembrolizumab in Advanced, Programmed Death Ligand 1-Positive Cervical Cancer: Results From the Phase Ib KEYNOTE-028 Trial. J Clin Oncol 35: 4035-4041. [Crossref]

43. Shin DS, Zaretsky JM, Escuin-Ordinas H, Garcia-Diaz A, Hu-Lieskovan S, et al (2017) Primary Resistance to PD-1 Blockade Mediated by JAK1/2 Mutations. Cancer Discov 7: 188-201. [Crossref]

44. Alsaab HO, Sau S, Alzhrani R, Tatiparti K, Bhise K, Kashaw SK, et al. (2017) PDand PD-L1 Checkpoint Signaling Inhibition for Cancer Immunotherapy: Mechanism, Combinations, and Clinical Outcome. Front Pharmacol 8: 561. [Crossref] 
45. Yang ZZ, Novak AJ, Stenson MJ, Witzig TE, Ansell SM (2006) Intratumoral CD4+CD25+ regulatory T-cell-mediated suppression of infiltrating CD4+ T cells in B-cell non-Hodgkin lymphoma. Blood 107: 3639-3646. [Crossref]

46. Latchman YE, Liang SC, Wu Y, Chernova T, Sobel RA, et al. (2004) PD-L1-deficient mice show that PD-L1 on T cells, antigen-presenting cells, and host tissues negatively regulates T cells. Proc Natl Acad Sci U S A 101: 10691-10696. [Crossref]

47. Parsa AT, Waldron JS, Panner A, Crane CA, Parney IF, et al. (2007) Loss of tumor suppressor PTEN function increases B7-H1 expression and immunoresistance in glioma. Nat Med 13: 84-88. [Crossref]

48. Marzec M, Zhang Q, Goradia A, Raghunath PN, Liu X, et al. (2008) Oncogenic kinase NPM/ALK induces through STAT3 expression of immunosuppressive protein CD274 (PD-L1, B7-H1). Proc Natl Acad Sci U S A 105: 20852-20857. [Crossref]

49. Atefi M, Avramis E, Lassen A, Wong DJ, Robert L, et al. (2014) Effects of MAPK and PI3K pathways on PD-L1 expression in melanoma. Clin Cancer Res 20: 3446-3457. [Crossref]

50. Santarpia M, Gonzalez-Cao M, Viteri S, Karachaliou N, Altavilla G, et al. (2015) Programmed cell death protein-1/programmed cell death ligand-1 pathway inhibition and predictive biomarkers: understanding transforming growth factor-beta role. Transl Lung Cancer Res 4: 728-742. [Crossref]

51. Thomas DA, Massague J (2005) TGF-beta directly targets cytotoxic T cell functions during tumor evasion of immune surveillance. Cancer cell 8: 369-380. [Crossref]
52. Gorelik L, Flavell RA (2001) Immune-mediated eradication of tumors through the blockade of transforming growth factor-beta signaling in T cells. Nat Med 7: 11181122. [Crossref]

53. Shevach EM (2009) Mechanisms of foxp3+ T regulatory cell-mediated suppression Immunity 30: 636-645. [Crossref]

54. Park BV, Freeman ZT, Ghasemzadeh A, Chattergoon MA, Rutebemberwa A, et al (2016) TGF 31 -Mediated SMAD3 Enhances PD-1 Expression on Antigen-Specific T Cells in Cancer. Cancer Discov 6: 1366-1381. [Crossref]

55. Stephen TL, Payne KK, Chaurio RA, Allegrezza MJ, Zhu H, et al. (2017) SATB Expression Governs Epigenetic Repression of PD-1 in Tumor-Reactive T Cells. Immunity 46: 51-64. [Crossref]

56. Mariathasan S, Turley SJ, Nickles D, Castiglioni A, Yuen K, et al. (2018) TGF attenuates tumour response to PD-L1 blockade by contributing to exclusion of T cells. Nature 554: 544-548. [Crossref]

57. Borcoman E, Le Tourneau C (2017) Pembrolizumab in cervical cancer: latest evidence and clinical usefulness. Ther Adv Med Oncol 9: 431-439. [Crossref]

58. Lheureux S, Butler MO, Clarke B, Cristea MC, Martin LP, et al. (2017) Association of Ipilimumab With Safety and Antitumor Activity in Women With Metastatic or Recurrent Human Papillomavirus-Related Cervical Carcinoma. JAMA Oncol. [Crossref]

Copyright: (C2018 Saglam O. This is an open-access article distributed under the terms of the Creative Commons Attribution License, which permits unrestricted use, distribution, and reproduction in any medium, provided the original author and source are credited. 